\title{
The Mammy’s Image in Chinese and American Literary Works*
}

\author{
LI Mei-qin \\ Zhejiang Gongshang University, Hangzhou, China
}

\begin{abstract}
Mammies depicted in Chinese and American literary works bear different characteristics due to different social and cultural backgrounds. Mammy figures in American literary works reflect the caste system based on racial hierarchy and the paternalistic slavery background, while the mammies' image in Chinese literary works mirrors caste system based on class and stratum as well as patriarchal society ruled by Confucianism. These different social and cultural backgrounds render mammy figures in the two literary traditions in different tastes. Mammy figures in American works are either virtuous and militant mammies identifying themselves with the white, or servants taking the white people’s kitchen as “my Kitchen”, who, by so doing, rob the black men of their manhood and deprive white women of their power. Mammy figures in Chinese literary works are the half-servants-half-masters who claim credit for themselves, privilege over other servants of lower stratum and exercise power in the name of their patriarchal masters.
\end{abstract}

Keywords: mammy’s image, different social and cultural backgrounds, caste system

\section{Introduction}

The mammy's image in both Chinese and American literary works is abundant in description, yet it is paid less attention in literary criticism. In China, from Historical Records (2007) written by Sima Qian to A Dream of Red Mansions (2008) written by Cao Xue-qin, lifelike mammies, mostly wet nurses, are described. From the visually non-stereotypical mammies (ranging from the earliest depictions of young, thin mammies in works such as Isabel Drysdale's Scenes in Georgia (1827) and Joseph B. Cobb’s Mississippi Scenes (1851) to later depictions of mulatto mammies in the works of Charles Chesnutt and Mark Twain) represented in the 19th-century literary works to the stereotypes of the large, de-sexualized, hearty, and happy mammy reflected in the 20th century, mammies are also depicted by such American writers as Margaret Mitchell, Fannie Hurst, William Faulkner, Toni Morrison, and Octavia Butler in different veins. These mammies, either wet nurses or old women serving their masters or the masters' children, bear different characteristics due to different social and cultural backgrounds. Their images vary according to their classes and races or their writers' racial or class perspectives; their functions are protean owing to their different individual, cultural, and social contexts.

\section{Differences of Mammy Image in Chinese and American Literature}

In Chinese literary works, the mammy's image ranges from being selfish, despotic, greedy, and ambitious to

\footnotetext{
* This paper is sponsored by National Social Science Fund (Project Number: 14BWW073) and Project of Zhejiang Province (Project Number: 1070XJ2913100).

LI Mei-qin, professor, Ph.D., Foreign Languages School, Zhejiang Gongshang University.
} 
being servile, helpful, and virtuous. Those negative images are usually wet nurses of the ancient emperors, carrying matters with a high hand and exercising power over others in the emperor's name. Take the mammy of Han Wu the Great (Named Liu Che, also Emperor Wu of Han) for example. Sima Qian depicts her as very powerful in Historical Record. Han Wu the Great always follows her advice, and even the courtiers have to show their respect to her. Her sons and grandsons tyrannize without restraint. Even when they commit crimes, they can evade justice without being punished. While in most literary works of Ming and Qing Dynasty, mammies are positive images of surrogate mothers to the children they nurse, in A Dream of Red Mansions, Cao Xue-qin describes mammies in quite a different way. Several literary works in Ming and Qing Dynasty describe the mammy image as closely related to the little masters they nurse. When the masters are at the transitional periods of their fate, these mammies usually stand up to meet the trial, sharing the dangers and pains together with their masters. The wet nurses usually pay special attention to the marriage of their masters (usually the mistresses that they have nursed), encouraging them to pursue after the ideal marriage without considering family status and class. Mammy Wang in The Happy Fate in Dreams (1993) encourages her mistress Shui Lan-ying to actively control her own destiny and helps her to date the handsome and talented scholar despite the fact that Shui Lan-ying's parents disagree the marriage. In History of Female Immortals (2008), Mammy Bao not only teaches the heroine Tang Sai-er knowledge from the Four Books (namely, the Great Learning, the Analects of Confucius, the Doctrine of the Mean, Mencius ) and the Five Classics (namely, the Book of Changes, the Book of Songs, the Rites, Collection of Ancient Texts, the Spring and Autumn Annals), but also teaches her military strategy and tactics. Mammy Bao also plays an important and active role in the process of Tang Sai-er's uprising. In Heroic Sons and Daughters (2013), the husband of the hero An Ji's wet nurse is a loyal and reliable servant. Wet Nurses in A Dream of Red Mansion are a group of experienced, mercenary, and calculating mammies having special position: They are the half-servants and half-masters in the Big House who are either superficially servile to their masters or claiming credit for themselves and becoming arrogant, while taking advantage of their power to bully people underneath them.

The characteristics ascribed to the mammy in American literature are closely related to her caretaker role for the whites' children. Her "virtues” were generally lack in other slave women, and she has been variously depicted as:

...self-respecting, independent, loyal, forward, gentle, captious, affectionate, true, strong, just, warm-hearted, popular, fearless, brave, good, pious, capable, thrifty, proud, regal, courageous, superior, skillful, tender, queenly, dignified, neat, quick, competent, possessed with a quick temper, trustworthy, faithful, patient, tyrannical, sensible, discreet, efficient, careful, harsh, devoted, truthful, neither apish nor servile. (Parkhurst, 1938, p. 352)

These characteristics can be easily found in Scarlett Ohara's mammy in Gone with the Wind (1936). Sharp-eyed and penetrating, she is at the same time the sharp-tongued surrogate mother who always watches the steps of Scarlett. She identifies herself almost as a white, considering herself superior to other black people in social status and is hostile to the "Yankees" and the "mean whites".

Yet the stereotype has not remained static throughout history, and its meaning stretched and adjusted according to changing cultural demands and the writers' demands. Take Dalilah in Imitation of Life (1933) for example. As a writer deeply involved in the Harlem Renaissance, especially with Zora Neale Hurston, Fannie Hurst creates a mammy figure who strives to keep the black identity before the time of the slogan "Black is 
beautiful" in her novel Imitation of Life. The mammy figure Dalilah fails to encourage her mulatto daughter Peola to take pride in her black "race" and dies heart-brokenly soon after Peola severs all local ties, marries a white man, and moves to Seattle. In some quite modern novels written by such African-American writer as Morrison, mammies either neglect their own children in favor of white children (e.g., Pauline Breedlove in The Bluest Eye) or break off with their own communities in favor of their white master's ( e.g., Ondine Childs in Tar Baby). All in all, the mammy is characterized as a faithful, obedient servant who places or is forced to place the well-being of white children and families above her own. True Bell in Jazz (1992), for instance, has to leave her own children in order to take care of the white Miss Vera Louis (just because True Belle is the one she "wanted" to take away) after Miss Vera is found pregnant because of her union with her father's black slave and is sent away by her parents.

\section{Reasons for the Differences}

The above analyses point to the fact that the mammy's image in Chinese literary works is quite different from that in American literary works, although such characteristics as servants and caretakers are their common features. Reasons vary from social to cultural level.

Socially speaking, although ancient Chinese society and US society are both caste society, the caste systems in these two countries are based on two different frames. In the case of US society, the caste system has been a hierarchy of privileges and restrictions based largely on race, which has become the dominant principle in this society. Mammies in the US social reality are actually those African-American women who are either slaves and chattels of the slaveholders or who have to earn the scanty living materials for the family in the Big House of white people. In slavery, slaves cannot even buy their freedom, and the work of the house slaves is comparatively lighter than the field slaves. Therefore, as house slaves, mammies are grateful to their masters. Loyalty is one way to show their gratitude to their masters. On the other hand, the mammy's position as the major emblem of black womanhood substantiates white subjectivity to be the source of dominant southern, and in turn national, memory. In both social mythology and in its reflection in US literary works as well as cinema, white male power has been assisted by the maintenance of black female stereotypes. The presentation of the image of the mammy has successfully reinforced and reiterated the social hierarchy maintained by the US caste system. Therefore, written from the perspective and values of the slave-owners, Gone with the Wind reaffirms the long-standing stereotypes of the hearty and happy mammy by letting her become the faithful and loyal servant to three generations of the White O'Hara. Just as Micki McElya (2007, p. 3), in her book, Clinging to Mammy, suggests, the myth of the faithful slave, in the figure of mammy, lingers because white Americans wish to live in a world where African Americans are not angry over the injustice of slavery. Assertions of African-American mammies' contentment with servitude alleviated white fears while reinforcing racial hierarchy.

Nevertheless, caste system in ancient China has been a hierarchy of privileges and restrictions based largely on class and stratum. Ancient China is a society of strict hierarchy in which one's stratum and status in a family depend mostly on the combined factors such as culture and psychology. The upper stratum of society such as feudal aristocrats is the privileged stratum that possesses lands, money, or political power, while servants serving at their homes are usually those who have to sell themselves to earn a living. Although they are servants, they just have loose relations of personal dependence on their masters. If they can afford to buy their freedom, the master 
cannot forbid them to do so. Mammy Lai in A Dream of Red Mansions, for example, can even have her own servants, and her grandson can even get an official position with the help of the master Jia Zheng. The people in $A$ Dream of Red Mansions fall into four categories according to the class analysis method: the imperial concubine of good and honest virtues representing the imperial power and the nobility, Jia family masters representing ordinary feudal noble stratum, the people of a special class such as Jia Bao-yu and Lin Dai-yu representing feudal nobility, and Jia family servants representing the lower strata of the feudal society. Among these servants, wet nurses are the privileged ones because of their close relationship with their masters. In A Dream of Red Mansions, for instance, the elderly mammies who have waited on the older generation of Jia family are even respected by the younger generations in this family. In Chapter 43, when people raise money to celebrate Wang Xi-feng’s birthday, the Patriarch of the family Jia Zheng's wet nurse Mammy Lai and a few of the older and most highly thought of nurses can sit on the stool,

...for it was the family custom to show more respect to domestics who had served the older generation than to the sons and daughters of the house. Hence Madame You and Xifeng remained standing while, after a show of declining, Lai Da's mother and three or four other old nurses sat down. (Cao, 2008, p. 1207)

The ruling class or stratum sometimes has to maintain the hierarchical order of the status quo to consolidate their power. A strange phenomenon in this hierarchy is that the mammy such as Mammy Lai can also become prosperous, owning her own buildings and pavilions with beautiful scenery, her grandson becoming magistrate of a county with the help of Jia Zheng, thus changing her stratum to that of upper one. Even so, she shows her respect and servility to her former masters by constantly expressing her gratitude and her respect to them. In Chapter 45, when Wang Xi-feng congratulates Mammy Lai on her grandson’s becoming an official, Mammy Lai says, "we owe it all to your kindness", and she continues, this time to her grandson,

...though you were born in bondage, our masters were kind enough to give you your freedom the moment you came out of your mother's womb. Thanks to the generosity above as well as your parents below, you were able to study like a young gentleman. (Cao, 2008, pp. 1265-1267)

"When you were twenty our masters were kind enough to help you purchase an official post" (Cao, 2008, p. 1267). Judging from these words, we can conclude that her class or stratum mobility is realized through the favor of the upper-class patriarch Jia Zheng, who, taking advantage of his feudal privilege, helps his wet nurse Mammy Lai and her family.

Cultural factors also account for the differences of the mammy's image presented in Chinese literature and American literature. The mammy's image in American literature is deeply rooted in paternalistic and White-patriarchal Slavery, which, as a cultural memory and rememory, is presented constantly to remind people of the past in which African-American suffer. As a system under which people are treated as property to be bought and sold, and are forced to work (Brace, 2004), slavery in American history is in essence the abuse of power and privilege of the white patriarch over black women and men. The paternalistic slave society and white patriarchal mythology has produced the Black Mammy. Though they are powerful and strong, maternal and proud, they are apparently under the control of paternalistic slave society. The mammy myth had distinct effects not only on white southern womanhood, but also on black southern manhood as well. According to Robert Staples (1970, p. 8), the notion of black matriarchy carries with it connotations of power and dominance, which 
rob black men of their masculinity and manhood. Thus, the creation and maintenance of the mammy in southern plantation society served a twofold purpose. It dislodged any trace of power from white southern women, and it led to a dissentious family structure in which black males would be deprived of their power and masculinity.

Eldridge Cleaver (1968), in Soul on Ice, analyzed the racial, sexual, and power relations in US society:

The myth of the strong black woman is the other side of the coin of the myth of the beautiful dumb blonde. The white man turned the white woman into a weak-minded, weak-bodied, delicate freak, a sexpot, and placed her on a pedestal; he turned the black woman into a strong, self-reliant Amazon and deposited her in his kitchen-that's the secret of Aunt Jemima's bandanna. The white man turned himself into the Omnipotent Administrator and established himself in the Front Office. And he turned the black man into the Supermasculine Menial and kicked him out into the fields. (p. 162)

The power inequities between men and women, Black and White are thus established. Examples are abundant in African-American novels, especially in Toni Morrison's fictions. In her novels, Morrison effectively reflects the mammies as deprive white women of their power and strip the black men of their manhood, making them suffer from emasculation. Ondine Childs in Tar Baby (1981) is a typical unconscious mammy who identifies more with her employers and the employer's culture than she does with her own people and her own culture. By calling her employer Valerian Streets’ kitchen “my Kitchen” (p. 51) and catering to Valerian’s whims, she internalizes Valerian's patriarchal ideas and strengthens Valerian into the omnipotent Administrator. Just like their surname Childs, she and her husband are indeed the children of Valerian who do as they are told. By preventing Valerian's Cinderella white wife Margaret from going into "her Kichen", Ondine becomes an accomplice of Valerian in rendering Margaret into an impotent, abnormal, and delicate freak who simultaneously finds pleasure and guilt in abusing her own son as Valerian's child. In The Bluest Eye (1970), before Breedloves move to Lorain, Pauline loves Cholly very much, and the love between them makes them both thrive. After they leave the backwoods of rural Kentucky to "urban” Lorain, Ohio, Pauline Breedlove becomes a typical mammy image that permeates the literature. "By loving, nurturing, and caring for her white children and family better than her own" (Collins, 2000, p. 71), Pauline is regarded as an ideal servant. Her white employer Fisher's house becomes the sanctuary where she can find "beauty, order, cleanliness, and praise" (Morrison, 1970, p. 127). More and more she neglects her own shattering and dirty house, her own "ugly" black children and her own irresponsible black man. The Breedloves' marriage becomes quarrelsome and violent. Cholly felt castrated and deprived of his dignity by the white man's ideal mammy "Polly". In their daily physical fights and Pauline's psychological abuse, Cholly becomes "dangerously free". "In a society in which patriarchal dominance and the supremacy of the phallus are considered coterminous", as Michele Wallace (1990) puts it, "the black man is perpetually denied the authority of the Great White Father” (p. 232). This loss of manhood culminates in Cholly's rape of his daughter Pecola in part to demonstrate his love and in part driven by an inner force almost against his desires (Morrison, 1970, p. 128).

Ancient China is patriarchal society ruled by Confucianism, which emphasizes "the three cardinal guides (the ruler guides his subject, the father guides his son and the husband guides his wife) and the five constant virtues (benevolence, righteousness, propriety, wisdom, and fidelity) as specified in the feudal ethical code”. The three cardinal guides establish the patriarch as the most respectful and authoritative figure in a family or a clan. Furthermore, there exists another hierarchy based on respect for seniority in ancient China. Seniority represents authority, which sometimes outmatches stratum. As the wet nurse of the most authoritative patriarch-the 
emperor in Han Dynasty, Han Wu the Great, the special position of Ha Wu the Great's Wet Nurse therefore is apprehensible. Wet nurses usually develop intimate relationship with their milked sons, and are usually considered almost as mothers by the people they nursed. Showing respect to his wet nurse is equivalent to showing respect to Han Wu the Great. It is also true of Mammy Lai, the wet nurse of the authoritative patriarch of Grand View Garden Jia Zheng in A Dream of the Red Mansions. When Baoyu's wet nurse Mammy Li claims credit for herself and becomes arrogant, drinking Baoyu's milk and tea, eating curds that Baoyu leaves for Xi Ren, bringing steamed stuffed bun back to her grandson without Baoyu's permission, wrangling with Baoyu's servant girls and making trouble out of nothing after losing her gambling, Baoyu has to put up with her. Even the sharp-tongued severe master Wang Xi-feng did not blame and punish her. Instead, she tries to cool her down by inviting her to eat some pheasant and drink wine. Just because she is the elderly wet nurse of Baoyu, the spoiled grandson of Lady Dowager and the future patriarch of the Big House, she takes it for grant that she is superior to other servants. Even Jia Lian's wet nurse Mammy Zhao, whom Jia Lian does not show much respect to, can get job opportunities from Wang Xi-feng for her sons. Indeed, although they remain submissive servants to their masters, mammies in this novel are superior to other servants. However, these mammies are still servants or slaves in the Big House, they cannot get rid of their fate of the servants even though they are half-servants-and-half-masters.

\section{Conclusion}

Mammy figures in American literary works reflect the caste system based on racial hierarchy and the paternalistic slavery background, while the mammies' image in Chinese literary works mirrors caste system based on class and stratum as well as patriarchal society ruled by Confucianism. These different social and cultural backgrounds render mammy figures in the two literary traditions in different tastes. Mammy figures in American works are either virtuous and militant mammies identifying themselves with the white, or servants taking the white people’s kitchen as “my Kitchen”, who, by so doing, rob the black men of their manhood and deprive white women of their power. Mammy figures in Chinese literary works are the half-servants-half-masters who claim credit for themselves, privilege over other servants of lower stratum and exercise power in the name of their patriarchal masters.

\section{References}

Brace, L. (2004). The politics of property: Labour, freedom and belonging. Edinburgh: Edinburgh University Press. Cao, X. Q. (2008). A dream of red mansions (X. Y. Yang \& G. Yang, Trans.). Beijing: Foreign Language Press.

Cleaver, E. (1968). Soul on ice. New York: McGraw-Hill.

Collins, P. H. (2000). Black feminist thought: Knowledge, consciousness, and the politics of empowerment. New York \& London: Routledge.

Hurst, F. (1933). Imitation of life. New York: P.F. Collier.

LI, X. X. (1993). The happy fate in dreams. Beijing: Beijing Normal University Press.

LV, X. (2008). History of female immortals. Jinan: Qi-lu Publishing House.

McElya, M. (2007). Clinging to mammy: The faithful slave in twentieth-century America. Boston: Harvard University Press.

Mitchell, M. (1936). Gone with the wind. London: Macmillan Publishers.

Morrison, T. (1970). The bluest eye. New York: Washington Square Press.

Morrison, T. (1981). Tar baby. New York: Plume.

Morrison, T. (1992). Jazz. New York: Plume. 
Parkhurst, J. W. (1938, July). The role of the black mammy in the plantation household. Journal of Negro History, 23(3), 351-358. Sima, Q. (2007). Historical record. Ha-er Bin: Northern Arts Publishing House.

Staples, R. (1970, January/February). The myth of the black matriarchy. Black Scholar, 12(6), 8-15.

Wallace, M. (1990). Black macho and the myth of the superwoman. London \& New York: Verso.

WEN, K. (2013). Heroic sons and daughters. Beijing: China Publishing House. 